\title{
Litteraturvetenskapliga termer inom engelskämnet på universitetsnivå
}

\author{
Anna Thyberg
}

\section{Inledning}

I den här artikeln vill jag problematisera några aspekter av ämneslitteracitet, vilket Ewa Bergh Nestlog definierar som: "att delta i språkliga sociala praktiker och använda det språk och de texter som ingår i praktiken. Litteracitet är alltså i första hand något människor gör med språk och texter" (2019: 15). Vid designen av olika kursmoment handlar en stor del av de didaktiska val som görs just om vad det är rent konkret som studenterna ska göra i seminarier och workshops. Det jag kommer att diskutera härrör från några didaktiska spörsmål angående en delkurs i litteraturvetenskap på engelskämnets första termin och det empiriska material som jag samlade in när jag undervisade på kursen för andra gången hösten 2017 Den här typen av kvalitativ och praktiknära forskningsstudie kan närmast liknas vid en form av aktionsforskning (Greenwood \& Levin 2007) eftersom jag ville undersöka ett fenomen i den egna undervisningen, närmare bestämt inslaget av disciplinspecifik terminologi. Det jag ville reda ut för mig själv var frågan hur man pedagogiskt designar en lärandemiljö så att studenter ser terminologin som redskap för att utföra olika uppgifter inom ämnet samt skapar ett socialt sammanhang som syftar till att studenterna uppfattar deltagande i samtalet som önskvärt och möjligt även för noviser.

Min upplevelse som lärare på kursen speglade givetvis enbart en aspekt av undervisningens mångfasetterade och dialogiska process. Utgångpunkten blev därför att studera studenternas uppfattningar om kursen med den övergripande målsättningen att ge plats för deras ämnesröster (Bergh Nestlog 2019: 20-21). Jag ville lyfta fram studenter som betydelsefulla medarbetare i processen med att förbättra kvaliteten inom högre utbildning. Studien kan också ses som ett led i en strävan att ge verksamma universitetslärare ett empiriskt underlag för pedagogiska beslut vad gäller ämnesspråk. Om studenter får kännedom om att en av anledningarna till förändringar av till exempel kursinnehåll är studier av andra studenters uppfattningar finns möjligheten att motivationen att engagera sig i inlärningen ökar eftersom det blir tydligt att studentperspektivet värdesätts (Angelo \& Cross 1993: 5). Undersökningen handlar om den betydelse som terminologi kan ha för studenter som rör sig mot en deltagarposition inom ämneslitteraciteten.

Eftersom min undervisning grundade sig i kursplanens förväntade studieresultat redovisas dessa mål nedan (för delkursinnehåll, se bilaga 1). I boken Universitetspedagogik framhåller Maja Elmgren och Ann-Sofie Henriksson vikten av att kursplaner och planering av undervisning bygger på konstruktiv länkning, att undervisningstillfällen och att examinationsformer ska konstrueras utifrån vad målen specificerar (2018: 163-67). Så här formuleras målen för den aktuella kursen i litteratur för vad studenten ska kunna (se även bilaga 1): 
- redogöra för grundläggande litteraturvetenskaplig terminologi samt tillämpa denna på litterära texter i både muntliga och skriftliga uppgifter,

- orientera sig inom litteraturvetenskap som forskningsområde,

- jämföra olika litterära genrer och former,

- kritiskt granska syfte och metod i litteraturvetenskapliga texter,

- reflektera över hur användbara olika teoretiska verktyg är vid analys av en specifik text.

Det första och sista kursmålet handlar om att studenterna ska lära sig förstå och tillämpa disciplinspecifik terminologi. Ur ett vidare perspektiv kan dessa termer sägas utgöra del av ett ämnesspråk, vilket Bergh Nestlog förklarar som "det språk som kvalificerade deltagare i en ämneskultur använder när de gör sina röster $i$ ämnet hörda för att kommunicera ämnesinnehållet med ämnesrelevanta strukturer för språk och andra resurser" (2019: 9, kursiv i original). I den här artikeln kommer jag att använda begreppet ämnesspråk på ett mer övergripande plan för det språkande som experter behärskar och ämneslitteracitet för de kompetenser att delta i ämnesspråkliga sammanhang som studenter/noviser gradvis utvecklar under sin tid på universitetet. Detta synsätt ligger i linje med det skifte som har skett från content literacy, med fokus på allmänna inlärningsstrategier för att förbättra läsförståelse, till disciplinary literacy, inriktat på ämnesspecifika lässtrategier och färdigheter (Shanahan \& Shanahan 2014: 628). Ämnets specifika vokabulär utgör ett betydelsefullt redskap för studenten på vägen mot en deltagarroll. Enligt Daniel Siebert med flera är just deltagandet avgörande för att utveckla ämneslitteracitet. Det räcker inte att lära sig allmänna tekniker och faktainnehåll, utan studenterna måste själva få uttrycka sig genom att öva på att tala om ämnet och skriva ämnestexter (Siebert m.fl. 2016: 28-29). Synsättet på lärande som en form av meningsskapande i ständig interaktion med andra människor innefattar ett tydligt dialogiskt perspektiv (Bergh Nestlog 2019: 11). Om det långsiktiga målet är att studenten går från novis till deltagare i en ämneslitteracitet blir socialiseringsprocessen ett betydande inslag.

Ur ett systemiskt-funktionellt lingvistiskt perspektiv framstår ämneslitteracitet som en entydigt positiv kompetens eftersom den innebär att individen får tillgång till ett nytt språkregister (Hållsten 2017: 15). Det resonemang som Bergh Nestlog utvecklar i det här temanumret visar på en möjlig väg framåt för att tydliggöra vad ämneslitteracitet är. Det kan röra hur textens metafunktioner påverkar skribentens olika valmöjligheter i skrivsituationen, vad gäller till exempel genrekonventioner och målgruppsanpassning (Bergh Nestlog 2019: 1415). I samklang med senare års satsningar på genrepedagogik (Johansson 2015) är det viktigt att metodiskt och systematiskt arbeta för att ge studenter eller elever redskap och stödstrukturer så att de kan utveckla de kompetenser som efterfrågas inom ämnet (Hållsten 2017: 14-15). Men det kan fortfarande vara otillräckligt att enbart sätta in åtgärder på individnivå för att studenterna ska kunna nå de krav som universitetet fastställt, vilket jag kommer att återkomma till nedan.

I den föreliggande studien är mitt syfte mer konkret att studera hur studenter ser på processen de genomgår när de tar sina första steg in $\mathrm{i}$ ämneslitteraciteten inom engelskämnet på en kurs i 
litteratur vid ett svenskt universitet. ${ }^{1}$ För att bryta ned syftet i observerbara delar bestämde jag mig för att undersöka vilka litteraturvetenskapliga termer studenterna skulle räkna upp, hur de förklarar dessa termer och studenternas uppfattningar om terminologi. Mina frågeställningar var:

a) Vilka litteraturvetenskapliga termer väljer studenterna att nämna?

b) Hur förklarar studenterna några av dessa litteraturvetenskapliga termer?

c) Vilka uppfattningar om litteraturvetenskaplig terminologi har studenterna?

\section{Teoretisk inramning}

Den kunskap som finns om ämnesspråk vad gäller litteraturvetenskapens didaktik på universitetsnivå tycks vara relativt begränsad. Laura Wilder menar att universitetslärare i regel tar grundläggande premisser för ämnets gestaltning och innehåll för givna (2002: 211-212). Detta är ett problem även på lägre stadier. Ronni Jo Draper och Jennifer J. Wimmer har funnit att grund- och ämneslärare ofta inte har verbaliserat vad ämneslitteracitet innebär i praktiken och de föreslår att ämnesdidaktiska kurser borde få större utrymme i lärarutbildningen så att ämnets innehåll och ämneslitteraciteten integreras (2015: 260-262). Bengt Göran Martinsson framhåller att det finns exempel på att svensk litteraturdidaktisk forskning rentav medvetet förbigåtts, till exempel i den statliga utredningen Läsandets kultur SOU 2012: 65, för att den "inte anses som användbar eller att den är en del av problemet - att den varit med och orsakat den rådande krisen [i allt sämre läsförståelse]" (2015: 173). Detta är beklagligt eftersom det begränsar möjligheten att öka inslaget av evidensbaserade rön vid designen av litteraturvetenskapliga kurser inom högre utbildning.

Vilken ställning har terminologi inom litteraturvetenskap? Todd Reynolds och Leslie S. Rush framhåller att terminologin tillhör ämneslitteraciteten på så vis att novisen behöver lära sig vilka ord som används i samtal inom ämnet för att kunna bli en fullvärdig medlem av denna diskurs (2017: 201). I en empirisk studie av expertläsare och novisläsare av en dikt fann Reynolds och Rush att noviserna hängde upp sig på att de inte kunde alla ord och istället försökte förstå texten utifrån textstruktur och personskildring. Expertläsarna använde andra strategier. De fortsatte fundera på vad orden betydde under läsningens gång, var öppna för olika möjliga tolkningar och förväntade sig att dessa skulle förändras kontinuerligt (Reynolds \& Rush 2017: 209). I S verige sker undervisningen i litteraturvetenskap inom engelskämnet för de flesta studenter på ett främmande språk, vilket i sig leder till en högre svårighetsgrad. För mina studenter var sannolikheten att ordkunskap skulle hamna i centrum därför större. Mitt bidrag till forskningsfältet handlar dock om termer som rör metaspråk för att tala om litteratur snarare än att förstå orden i en litterär text.

Terminologi var visserligen ett kursmål för delkursen men färdigheter inom litteraturvetenskap som ämne innefattar i ett mer generellt perspektiv även kritiskt tänkande, analytisk förmåga och språklig kompetens. Jag vill därför beröra en del av dessa faktorer i den här artikeln. I litteraturvetenskap är särskilt akademiskt skrivande en central beståndsdel eftersom förmågan att analysera skönlitteratur oftast examineras i skriftliga arbeten och så även

$1 \mathrm{Jag}$ vill passa på att tacka alla informanter som har ställt upp och delat med sig av sina tankar och texter. Utan deras generösa medgivande hade den här studien inte varit möjlig att genomföra. 
på min delkurs. Tyvärr har inte heller akademiskt skrivande inom ämnet litteraturvetenskap studerats ingående empiriskt, till skillnad från hur det förhåller sig inom naturvetenskap (Wilder 2012: 4; Reynolds \& Rush 2017: 199). I detta sammanhang bör även strukturella faktorer beaktas, vilka påverkar omfattningen och inriktningen på förekommande skrivuppgifter. Här finns det naturligtvis betydande skillnader mellan olika delar av världen och även nationellt mellan olika lärosäten. Alister Cumming fann till exempel att de kanadensiska studenterna i hans studie sällan fick tillfälle att skriva längre texter under sina första universitetskurser (2006: 160). En ytterligare komplikation kan vara att merparten av lektionstiden på litteraturvetenskapliga kurser ägnas åt att tala om litteratur snarare än hur man skriver om litteratur (Garrett-Petts 2013: xiii; Lang 2016: 74), vilket kan vara problematiskt eftersom studenter behöver få öva på just det som de senare ska bedömas på (Lang 2016: 75; Elmgren \& Henriksson 2018: 163-164, 170-171). Det handlar även om progression mellan olika stadier i skolsystemet (Lee \& Goldman 2015: 218-220) och målen som uttrycks i kursplaner i högre årskurser. I en svensk kontext argumenterar Liviu Lutas för att litteraturvetenskaplig teori bör inkluderas redan på gymnasiet dock med utgångspunkt i elevernas egna tolkningar och inte som en förkonstruerad analysmodell eller lista av termer (2014: 128, 137). Som synes i lärandemålen ovan för den inledande litteraturkursen förväntas studenterna kunna visa sina färdigheter att använda terminologi som analysverktyg när de sedan kommer till universitetet.

\section{Didaktiska reflektioner}

För att närmare beskriva bakgrunden till studien vill jag nu diskutera några reflektioner under min inledande lärargärning. Huvudsakligen uppfattade jag terminologin i litteraturkursen som problematisk utifrån ett ämnesdidaktiskt perspektiv. Det var svårt att utforma undervisningen om terminologin så att den skulle upplevas som meningsfull. För att skapa en stödstruktur satte jag samman en gloslista över dramatiktermerna, men det innebar samtidigt att en mekanisk inlärning uppmuntrades (se bilaga 2). I momentet i kursen ingick också en övning där studenterna turades om att förklara terminologin för varandra. Vid ett annat tillfälle arbetade de i grupp med frågor på texterna med syfte att applicera termerna. Jag påpekade att de skulle få poäng för termer i den avslutande skrivuppgiften (se bilaga 3) och tillsammans med en kollega skulle jag ge en muntlig examination av terminologi samt tillämpning av densamma på litterära texter (se bilaga 4). Sammantaget betonades alltså terminologins betydelse för studenterna starkt. Visserligen är det ett förväntat och önskvärt utfall att studenter prioriterar de moment som kommer på tentamen och poängen med konstruktiv länkning är att läraktiviteter direkt ska leda till den kunskap och färdigheter som senare examineras (Elmgren \& Henriksson 2018: 166). Men det innebär att terminologi som kursmål hindrade mig från att behandla andra kursmål på ett djupare plan och från att inkludera fler litterära verk.

Vad beträffar kursinnehållet vände jag mig mot det instrumentella i att studenterna var tvungna att lära in och använda vissa termer för att få godkänt på kursen. Detta inslag i kursplanen fungerade i själva verket som ett sätt att göra litteraturvetenskap kvantifierbar. Det är relativt enkelt att objektivt mäta hur många termer studenterna kan definiera eller använda $\mathrm{i}$ en text, men är ett yttrande verkligen mer avancerat ju fler teoretiska termer talaren eller skribenten använder? I en studie om narratologins roll på gymnasiets svenskkurser, refererar 
Lutas till kritik av tendensen i fransk gymnasieutbildning att testa eleverna på narratologiska termer och han menar att för eleverna är "kunskapen om terminologi mindre viktig när man undervisar om berättarteknik än insikterna om berättarteknikens komplexitet och möjligheter" (2014: 139). Det ska dock tilläggas att Lutas finner i sin undersökning att gymnasieelever klarar av att hantera komplicerade litteraturvetenskapliga teoretiska begrepp under förutsättning att det sker induktivt (2014: 141). Ett annat sätt att undvika att terminologi upplevs som tomma fraser föreslås av Siebert med flera (2016: 29). De ger ett exempel på hur lärare kan använda sig av rollspel i undervisningen för att simulera ett fall inom ett yrkesområde, i det här fallet uppsättningen av en pjäs för dramastudenter. Studenterna intog olika positioner i diskussionen beroende på vilken yrkesroll de hade fått sig tilldelade och därmed kom samtalet att efterlikna experternas sätt att interagera (2016: 29). Ämneslitteraciteten fylldes i detta exempel med innebörd och förhoppningen torde vara att studenterna kunde uppfatta termerna som nödvändiga redskap för att kunna dryfta angelägna problem inom ämnesområdet. Hur skulle en koreograf tala om den här iscensättningen? Vilka termer behöver en regissör kunna använda?

Ett annat problem var att ett moment som litteraturvetenskaplig terminologi skulle kunna leda till en förminskning av skönlitteratur som konstform, vilket kan kopplas till synen på dess roll i samhället. Martinsson nämner följande möjliga anledningar till att skönlitteratur tappat i värde inom utbildningsväsendet i Sverige: "nya teoretiska paradigm inom pedagogik, didaktik och litteraturvetenskap . . . den allmänna samhällsutvecklingen från 1960-talet och framåt, manifesterad bland annat i ungdomsskolans och högskolans breddade rekrytering" (2015: 175). Om skönlitteratur ses som vilken text som helst kan studenternas uppfattningar om litterär läsning påverkas negativt. Formalisering av analysmetoder inom litteraturområdet har kritiserats sedan nykritiken tog fart på 1930-talet (Rosenblatt 1995: 25). Louise M. Rosenblatt framhåller att elever bör få ägna sig åt estetisk, upplevelseorienterad läsning (1995: 33). I motsats till denna uppfattning fann jag att mina studenter snarare tvingades in i en formelartad läsart, vilket Rosenblatt kallar efferent, informationsorienterad läsning (1995: 32). Det är inte fråga om att ägna sig enbart åt det ena eller andra sättet att läsa litteratur utan elever behöver utveckla en allsidig förmåga som kan anpassas efter situationen och syftet med läsningen (Rosenblatt 1995: 259-260).

Givetvis skulle det efferenta sättet att läsa även kunna betecknas som en inskolning av studenterna i disciplinen, en del av ämneslitteraciteten, särskilt om mer strukturalistiskt grundade perspektiv betonas. Gerald Graff berättar en anekdot om hur han som collegestudent var helt främmande för vad det var han förväntades göra på litteraturlektionerna. Det var först när han fick höra att olika forskare var oense om tolkningen av slutet på Huckleberry Finn som han förstod syftet med litteraturvetenskaplig analys och kunde delta i klassrumsdiskussionen (Graff 2000: 43). Även om jag naturligtvis ville att studenterna skulle förstå kursmålen och uppskatta den intellektuella utmaningen att finna bevis i texten för sina tolkningar, önskade jag också att de skulle bli inspirerade av skönlitteraturens inneboende kraft och möjlighet till stimulans av empati och föreställningsförmåga (Keen 2007: 71-72). Jag var rädd att den dolda läroplanen (Broady 2007) i mitt klassrum förspråkade efferent läsning av skönlitteratur (Rosenblatt 1995: 32) och att kvaliteten i litteraturvetenskapliga analyser kunde reduceras till antalet använda termer. 


\section{Ämneslitteracitet som socialiseringsprocess}

Kursmomentet skavde även utifrån en ideologisk ståndpunkt. Jag föreställde mig att en del studenter kunde känna sig främmande i en kontext där den här typen av ämneslitteracitet framstod som krav. I enlighet med Pierre Bourdieus teori om kulturellt kapital kan ämneslitteracitet liknas vid en reproducerande process $\mathrm{i}$ och med att utbildning de facto fungerar som ett sorteringsverktyg av status och prestige i samhället (1986: 47-51). De studenter som har socialiserats in i det språkbruk som utmärker starkt kulturellt kapital kommer därför att premieras i högre utbildning och gynnas av systemet på olika sätt vilket leder till att status quo upprätthålls. Studier av barns språkutveckling visar att antalet ord som föräldrar yttrar till sina barn varierar från 620 till 2150 ord/timmen beroende på samhällsklass, vilket redan under barnens första tre år befäster en ojämlik språkutveckling (Hart \& Risley 1995: 132). Det är tids- och arbetskrävande att erövra kulturellt kapital och förutsätter tillräckliga ekonomiska resurser (Bourdieu 1986: 49-50). Detta innebär att ungdomars ordförråd kan variera kraftigt beroende på socioekonomiska faktorer.

Lösningen är dock inte så enkel som att universitet först ger missgynnade studentgrupper möjlighet att utöka sitt ordförråd och sedan lyckas de med sina studier. Socialt, emotionellt och identitetsmässigt riskerar studenter att drabbas av negativa konsekvenser när de tillägnar sig ett akademiskt språkbruk. Elizabeth M. Lee och Rory Kramer konstaterar att "[s]ocially mobile students face a unique pressure to acclimate to the dominant elite culture" (2013: 19). Det handlar alltså om ett slags assimileringstvång in i en annan social och kulturell krets. Lee och Kramer fann även att deras informanter upplevde en "loss of connection to family and homecommunity peers" som en direkt följd av sin tid på college (2013: 25). Assimileringsprocessen förutsätter att den tidigare gruppidentiteten och solidariteten med hemmiljön urholkas och kanske till och med överges. En respondent i Lees och Kramers studie gör följande uttalande om hur hon försöker motverka den här distanseringen genom att förändra sitt sätt att tala i möten med släkt och vänner: "'I'm so, like, constantly checking myself when I go home, I don't want to use these big academic jargon-y words that Linden [pseudonym för ett prestigefyllt college] demands you use here, [that I] never ever knew before coming to Linden'" (2013: 27). Även om inträdet i ämneslitteraciteten i den här bemärkelsen kanske är en oundviklig del av klassresan, kan upplevelsen vara en smärtsam påminnelse om att inte duga och ett underkännande av de andra typer av kulturellt kapital som studenten äger (Soria \& Stebleton 2013: 140). Jag anser att denna dimension av ämneslitteracitet inte bör glömmas bort.

Med tanke på den akademisering och marknadifiering av högre utbildning som AnneCharlotte Ek med flera (2011: 2) menar har skett, är en legitim fråga huruvida studenterna själva efterfrågar social mobilitet uppåt på samhällsstegen. För en del studenter är målet en yrkesexamen och de är då mindre intresserade av akademin som institution. Studenter positioneras likväl som konsumenter på en utbildningsmarknad på grund av politiska beslut för att stärka studenters möjlighet att jämföra kvaliteten mellan olika utbildningsprogram (Modell 2005: 538). Denna positionering har stärkts av att den minskande studenttillströmningen under senare år har lett till att lärosätena alltmer fått satsa på marknadsföring och varumärkesbyggande (Modell 2005: 545). Men vilken utbildningsnivå individen strävar efter kan också hänga samman med självförtroende och klasstillhörighet. Nicole M. Stephens med flera hävdar att "[t]he nature and content of people's selves -whether individuals identify as 
'students' and understand school as something for 'people like me'- will, in turn, influence whether or not a given strategy for improving academic performance will be effective" (2012: 732). Åtgärder för att göra skolsystemet mer jämlikt riskerar därför att bli uddlösa på grund av att vissa av de samverkande faktorerna inte tagits i beaktande, till exempel individens identitetskonstruktion och självbild. Konsekvenserna både på individ- och samhällsnivå visas av att både inträde till och avbrott i högre studier är generellt sett vanligare för grupper med svagare kulturellt kapital (Stephens m.fl. 2012: 726; Soria \& Stebleton 2013: 142).

Med andra ord är det inte konstigt att lärosäten strävar efter mer genomgripande förändringsprocesser för att öka genomströmningen. Det ingår också i uppdraget till svenska universitet och högskolor. Redan 1992 fastställdes avsikten att öka antalet studenter i varje årskull som går vidare till högre utbildning i högskolelagen, 1 kap. 5 §: "Högskolorna skall också aktivt främja och bredda rekryteringen till högskolan" (SFS 1992: 1434). Den här satsningen har ökat spridningen i studentpopulationen vad avser till exempel kunskapsnivå, bakgrund och studievana (Hjalmarsson m. fl. 2017: 37; Modell 2005: 544). Katerina Dodou menar dock att när "pedagogiska utmaningar kopplade till en bredare studentrekrytering definieras som en fråga om mångkulturalitet, tolerans och självkännedom” hindras lärosäten från att fokusera på kärnuppdraget att introducera studenterna i "vetenskapliga förhållningsoch arbetssätt" (2015: 178). Uppfattningen att det inte längre är möjligt att undervisa enligt gängse tradition skulle därmed leda till en negativ, självuppfyllande profetia. Tvärtom framhäver Jan Hjalmarsson med flera att "det inte bara är studenterna som måste anpassa sig till de nya praktikerna. Delaktighet innebär att också akademin måste anpassa sig till studentgruppernas förutsättningar" (2017: 38). Sådana anpassningar kan bestå av att kurser designas så att de inte förutsätter att studenterna redan har tillägnat sig en viss vokabulär eller sätt att studera före kursstarten, liksom att lärare ges timmar för individuell- eller grupphandledning och att lärare förändrar sin syn på vad som är kännetecknande för framgångsrika studenter så att de har positiva förväntningar på alla studentgrupper (Thompson 2019).

\section{Demokratiperspektiv}

Ur en demokratisk synvinkel handlar anpassning om medinflytande, vilket även det stipuleras i högskolelagen, 1 kap. $4 \S$ : "Studenterna skall ha rätt att utöva inflytande över utbildningen vid högskolorna" (SFS 1992: 1434). Med ett mer radikalt synsätt medför studenternas delaktighet något mer än medbestämmande om utformning och stoffval i kurser. I sin bok om frigörande pedagogik lyfter Paulo Freire (1977) fram den unga människans rätt och förmåga till empowerment. Genom att ta makten över sin inlärning och använda sin kunskap och sina färdigheter för att till exempel motverka samhälleliga orättvisor erfar studenterna att deras egen drivkraft kan göra verklig skillnad. Ur ett socialkonstruktivistiskt perspektiv kan ämnesspråk ses som "unique and specialized bodies of knowledge to be constructed, questioned, and embodied" (Draper \& Wimmer 2015: 254). Vad avser universitetens demokratiska uppdrag vore det önskvärt att erkänna individens rätt att välja mellan att delta i konstruktionen av de språkbruk som erbjuds, att ifrågasätta eller rentav att markera sitt motstånd mot dessa sätt att tala i olika akademiska sammanhang. 
Jag undrade om studenterna i min kurs upplevde att de kunde göra motstånd genom att exempelvis kritisera det språkbruk som påbjöds bland annat genom gloslistan. Kände de sig bekväma med att använda termer såsom peripeteia, anthropomorphism, denouement? Det är också befogat att fundera på vilka mottagare vi universitetslärare menar att studenterna ska föreställa sig i en skrivuppgift eller muntlig presentation inom kursen. I högskolelagen, 1 kap. $8 \S$, står det uttryckligen att studenter på grundnivån ska kunna "utbyta kunskaper även med personer utan specialkunskaper inom området" (SFS 1992: 1434). Om jag i min undervisning så starkt fokuserar på litteraturvetenskapliga termer, särskilt de tagna ur traditionen av grekisk och fransk litteraturhistoria, har det en elitistisk underton snarare än en betoning på förmågan att kunna tala enkelt om komplicerade fenomen. Eftersom en vanlig tendens i studentarbeten är att de försöker tala/skriva komplicerat och teoretiskt till den grad att det tangerar en parodi på den akademiska diskursen anser jag att undervisningen snarare borde motverka vad som uttrycks i Esaias Tegnérs kloka devis: "Det dunkelt sagda är det dunkelt tänkta" (1847-1851: 160).

\section{Material och metod}

Studien är som sagt en form av aktionsforskning, även om den inte inbegriper ett samarbete mellan forskare och verksamma lärare. Aktionsforskning definieras av Davydd Greenwood och Morten Levin som "a professional action researcher and the members of an organization, community, or network ('stakeholders') who are seeking to improve the participants' situation. AR [Action Research] promotes broad participation in the research process and supports action leading to a more just, sustainable, or satisfying situation" (2007: 3). Men i den här studien sammanfaller i stället de två rollerna. Ett kännetecken för aktionsforskning som uppfylls är att undersökningen grundar sig $\mathrm{i}$ ett problem formulerat av någon som är verksam i professionen.

Materialet består av en kvalitativ enkätstudie som mest kan liknas vid en pilotstudie vad avser storlek och utformning. Anledningen till att jag ville göra en enkätundersökning snarare än intervjuer var för att kunna inkludera fler informanter under den tidsrymd som fanns till förfogande (Bryman 2016: 222). Nackdelen med den här metoden var att jag inte kunde be respondenterna att vidareutveckla sina svar, att de riskerade att tröttna på att svara ifall frågorna inte kändes relevanta och att antalet öppna frågor behövde begränsas då de flesta informanter föredrar att inte behöva skriva långa svar (Bryman 2016: 223-224). Enkäten besvarades av 68 studenter på grundnivå samt åtta studenter på kandidat- och magisternivå (termin 3/5). Utformningen berodde på att det var viktigt att enkäten gick fort och lätt att svara på för att så många studenter som möjligt skulle vilja delta. Dessutom var tiden för förstaterminsstudenterna begränsad (ca 20 minuter vid slutet av ett lektionspass och då skulle de också fylla i en kursutvärdering). Kandidat- och magisterstudenterna besvarade enkäten digitalt och skickade mig dokumentet per mejl. Jag gav dem ingen instruktion kring användning av hjälpmedel när jag kontaktade dem så det stod dem fritt att använda internet.

Urvalet är baserat på vad Martyn Denscombe kallar en utforskande (exploratory) ansats vilket lämpar sig när forskningsstudien syftar till att undersöka "relatively unexplored topics and as a route to the discovery of new ideas or theories" (2014: 33). Med tanke på att litteraturdidaktik inom engelskämnet på universitetsnivå tycks vara relativt outforskat inom en svensk kontext vad gäller litterär terminologi, ansåg jag det lämpligt att inleda med en 
småskalig studie för att se vilka intressanta aspekter som skulle yppa sig. Det kan delvis betecknas som ett konsekutivt urval (Daniel 2011: 255) då alla studenter som var registrerade på grundkursen tillfrågades om deltagande i studien. Den här typen av urval innebär givetvis att resultatet inte kan betraktas som representativt för andra populationer (Denscombe 2014: 51).

Alla medverkande studenter har gett skriftligt medgivande till att medverka i studien efter att ha fått information om frivillighet, sekretess och möjlighet att när som helst avbryta deltagandet i enlighet med Vetenskapsrådets (VR) etiska regler. Genom att informera studenterna om syftet med enkäten, att resultatet skulle publiceras, att deltagande var frivilligt och möjligt att avbryta vid valfri tidpunkt har jag strävat efter att uppfylla vad VR kallar "informerat samtycke" (2017: 29).

Anonymitetskravet har varit svårare för mig att uppfylla i så måtto att det handlar om aktionsforskning i den pedagogiska praktiken (Vetenskapsrådet 2017: 41). Enkäten fylldes i anonymt samtidigt med en skriftlig utvärdering. Det är omöjligt att härleda några enskilda svar till särskilda studenter, vilket skyddar studenternas identitet, dessutom kan inte uppgifterna betraktas som känsliga. Studenterna på kandidat- och magisternivå (termin 3/5) går ämneslärareller språk, kultur och kommunikationsprogrammet. Konfidentialitetskravet uppfylls inte här eftersom dessa studenter har svarat per mejl. Dokumentationskravet uppfylls genom att insamlat material enbart kommer att användas för forskningsändamål och inte spridas till tredje part (Vetenskapsrådet 2017: 42).

Förstaterminsstudenterna hade vid svarstillfället haft undervisning i litteraturvetenskap inom engelskämnet sedan kursstarten i september. Först hade de en introducerande delkurs, vilken följdes av en delkurs i poesi. Enkäten utfördes i december när de stod i begrepp att avsluta delkursen i narrativ och dramatik och veckan efter skulle de ha en muntlig tentamen på litteraturvetenskapliga termer och ingående texter. Studenterna på första terminen var antingen registrerade på ämneslärar-, administrations-, språk, kultur och kommunikationsprogrammet, eller fristående kurs. Eftersom det inte är möjligt för mig att skilja på dessa grupper inom materialet på förstaterminen då de har svarat anonymt och var i blandade grupper, har jag heller inte åtskilt mellan grupperna på termin 3/5. Rent generellt kan man konstatera att lärarstudenterna i regel utgör en tredjedel av studenterna på termin 1. Det brukar vara ungefär lika många studenter som läser de andra två programmen medan antalet fristående kursare och utbytesstudenter utgör ett tiotal totalt.

Undersökningen har genomförts på engelska och jag har rättat stavfel och språkliga brister för att minska störningen i kommunikationen med läsaren. Förstaterminsstudenterna svarade för hand vilket naturligtvis ledde till en större grad av språkliga misstag då de inte hade hjälp av stavningskontroll. Bortfallet består av 12 studenter på termin $3 / 5$ vilket innebär en svarsfrekvens på $40 \%$ för den gruppen. På termin 1 besvarade 68 av ca 75 registrerade studenter enkäten (svarsfrekvens $91 \%$ ).

\section{Enkäten}

Frågorna i enkäten berörde litteraturvetenskapliga termer samt feedback på skriftliga uppgifter (se bilaga 5 och 6). Frågorna om akademiskt skrivande och feedback (fråga 9-2) behandlas inte i artikeln. Enkäten innehöll såväl frågor med fasta svarsalternativ (fråga 1-2, 5-11) som 
öppna svar (fråga 3-4). Frågorna med fasta svarsalternativ hade även ett alternativ som erbjöd respondenten att skriva ett eget svar eller en kommentar. För fråga 1 kan alternativen tolkas som ledande, men tanken var att ge ett positivt, ett neutralt, samt ett negativt alternativ. Trots att detta inte är en kvantitativ studie har jag valt att utföra vissa enkla beräkningar för att kunna jämföra och visa i vilken mån olika mönster träder fram i materialet som helhet. På grund av att en del studenter har hoppat över någon fråga eller att andra har valt flera svarsalternativ blir summan inte alltid 100 i procentberäkningarna.

Vid bearbetningen av materialet uppstod en fråga om klassificering av termerna som studenterna hade nämnt. En vanlig indelning av ordtyper på engelska är den som nestorn inom ordinlärning Paul Nation lanserade 1990: "high frequency (or general service) vocabulary, subtechnical or academic vocabulary, technical vocabulary, and low frequency vocabulary" (Nation \& Kyongho 1995: 35). En korpusbaserad ordlista som är vanligt förekommande inom akademisk literacy är Academic Word List (Coxhead 2000), men varken denna eller den tidigare General Service List (West 1953) innehåller specifikt litteraturvetenskapliga termer. Det finns dock många internetbaserade listor av sådana termer. ${ }^{2}$ Den här typen av ordlistor ingår också i en del handböcker för engelsk litteraturvetenskap på universitetsnivå, vilket det gjorde i den handbok som användes på den kurs där jag undervisade: Reading and Writing about Literature: A Portable Guide (2017) av Janet E. Gardner och Johanna Diaz. Deras lista över terminologi omfattar ett 270-tal poster och den gloslista som jag ställde samman till studenterna var mestadels tagen direkt från handboken (2017: 185-208; se bilaga 2).

I det här fallet valde jag att inte utgå från teoretiska klassificeringar eftersom mitt övergripande syfte var att göra studenternas röster hörda. Därför återkom jag till förstaterminsstudenterna och magisterstudenterna i april 2018 för att be tre mindre grupper av dem som deltagit i studien (fem respektive fyra andraterminsstudenter och fem masterstudenter) att dela upp termerna i grundläggande och avancerade termer. Det är termerna från termin 1 som har använts för detta syfte och studenterna sorterade termerna på lappar i två kuvert märkta basic och advanced.

\section{Analys}

Här kommer jag att diskutera vilka termer studenterna nämner, hur de förklarar olika termer samt deras uppfattningar om terminologi.

\section{Terminologi som studenterna valde att räkna upp}

Med tanke på kursmålet ville jag se vilka termer som studenterna skulle nämna (fråga 3: If you can remember, please list some of the literary terms that you learned in the courses in literature), även om ordinlärning inte bör reduceras till en ytlig uppräkning utan snarare innefattande både förmåga till definition och användning $\mathrm{i}$ tal och skrift. För att ge läsaren tillgång till respondenternas svar listar jag i tabell 1 termerna i fallande ordning baserat på hur många enskilda studenter som har nämnt termen i fråga.

2 Se t.ex. https://literaryterms.net/; https://literarydevices.net/; http://web.cn.edu/kwheeler/lit_terms.html; https://www.litcharts.com/literary-devices-and-terms. Nedladdade 2018-12-15. 
Tabell 1. Fråga 3: Litteraturvetenskapliga termer, studenter på termin 1

\begin{tabular}{|l|l|}
\hline $\begin{array}{l}\text { Antal studenter } \\
\text { temämner } \\
\text { termen }\end{array}$ & Termer \\
\hline 24 & plot \\
\hline 18 & characterization \\
\hline 18 & narrative, narrator \\
\hline 10 & catharsis \\
\hline 10 & homo/heterodiegetic narrator \\
\hline 9 & protagonist \\
\hline 8 & mind style, act, setting \\
\hline 6 & black comedy/comedy \\
\hline 5 & $\begin{array}{l}\text { focalization, diction, } \\
\text { denouement, hamartia, playwright }\end{array}$ \\
\hline 4 & story, soliloquy \\
\hline 3 & $\begin{array}{l}\text { style, antagonist, anagnorisis, } \\
\text { peripeteia, theme, hero/heroine, } 4^{\text {th }} \text { wall }\end{array}$ \\
\hline 2 & $\begin{array}{l}\text { character, climax, diegesis, } \\
\text { round/flat character, tragedy, anthropomorphism, personification, allusions, } \\
\text { Marxist criticism, comic relief, aside, dramatic monologue, direct/indirect } \\
\text { discourse, rising/ falling action }\end{array}$ \\
\hline 1 & $\begin{array}{l}\text { allegory, analepsis, analogy, Aristotelian unity, blocking. catastrophe, } \\
\text { foreshadowing, homonyms, imagery, melody, metaphor, mimesis, poetry, } \\
\text { proscenium arch, prop, set, spectacle, stage, upstage }\end{array}$ \\
\hline
\end{tabular}

Som synes i tabellen är det verkligen en stor mängd termer som totalt sett nämns av förstaterminsstudenterna, vilket förmodligen är en följd av att de nästföljande vecka skulle ha muntlig tentamen på just terminologi. Oavsett orsaken kan det vara intressant att notera vilka termer som flest studenter räknar upp. De tre termer som toppar listan vad gäller frekvens kommer från delkursen i narrativ, medan den fjärde termen hör till dramatik. Sedan följer sex termer från narratologi och två från dramatik. På nionde plats i listan (termer som nämns av fem studenter) är det en term från narratologi och fyra från dramatik. Det tycks alltså som att det finns en svag tendens att studenterna har lättare att komma ihåg termer från narrativdelen av kursen, vilket är intressant med tanke på att de inte fick någon ordlista för de termerna.

Utifrån den klassificering av termerna som studenterna fick genomföra är de första tre på listan grundläggande termer: plot, characterization och narrative. Men på en delad fjärdeplats kommer catharsis och homodiegetic/heterodiegetic narrator, vilka en del av studenterna betecknar som avancerade termer. ${ }^{3}$ För förstaterminsstudenterna kommer den grundläggande termen protagonist på femte plats, men en annan grundläggande term, character, kommer intressant nog först på tolfte plats. Character skulle många säkert uppfatta som en allmän term och inte en litteraturvetenskaplig sådan. I en litteraturvetenskaplig analys är det dock viktigt att konsekvent använda character när romanfigurerna åsyftas för att visa en medvetenhet om att det handlar om fiktiva konstruktioner och inte verkliga personer. 
Bland de termer som enbart nämns av förstaterminsstudenterna finns dels narratologiska begrepp såsom: plot, characterization, mindstyle, homodiegetic and heterodiegetic narrator, dels dramaturgiska termer såsom: diction, upstage, blocking, fourth wall, proscenium arch, och melody. Kandidat- och magisterstudenterna nämner dock vissa begrepp som förbisågs av förstaterminsstudenterna. Det är främst termer för akademiskt skrivande som studenterna säkert stött på i arbetet med självständiga arbeten: coherence, ellipsis, rhetorical question och scope, men också sådana som hör till den teoretiska sfären av litteraturvetenskap: contextualized reading, gender, narratology, critical race theory, archetype och defamiliarization. Respondenterna på termin 3/5 nämner också termer som rör poesi i högre grad: rhyme, couplet, limerick och stanza. Att förstaterminsstudenterna inte nämnde poesitermer kan bero på att delkursen i poesi hade avslutats tidigare under terminen, vilket kan gjort dem mindre benägna att tro att dessa termer efterfrågades i slutet av kursen i narrativ och dramatik. I materialet från termin 1 är det två studenter som nämner en teoretisk term och intressant nog är det samma term: Marxist criticism.

I det material som förstaterminsstudenterna hade tillgång till (gloslistan och bildpresentationer publicerade på lärplattformen) ingick ett nittiotal termer. Av dessa var det drygt tjugo termer som inte nämndes av någon student: subplot, dialogue, satire, stage directions, director, naturalistic acting, downstage, elements of drama, exposition, subtext, in medias res, prolepsis (flashforward), focaliser, omniscient narrator/zero focalisation, limited omniscient, internal focalisation, external focalisation, free indirect discourse, villain, sympathetic/unsympathetic character, storyworld/milieu, mood, symbol, simile. Ungefär hälften av dessa är från gloslistan för dramatik och hälften från bildpresentationerna för narrativdelen av kursen. För dramatik rör flera av de förbigångna termerna teaterproduktion och det är förståeligt om studenterna uppfattar dessa som mer perifera eftersom de läste en pjäs utan att se den framförd på scenen. Att dramaturgiska och teatertekniska termer upplevdes som onödiga uttrycktes också av en student i en kommentar till den här frågan. Från narrativdelen är det en övervikt av narratologiska termer som inte nämns av någon student vilket skulle kunna bero på att terminologi är ett särskilt problematiskt område inom den här teoribildningen, bland annat därför att forskarna har lanserat olika begrepp för samma fenomen. När några av studenterna senare ombads kategorisera begreppen efter svårighetsgrad hamnar dock flera narratologiska begrepp i den grundläggande kategorin så anledningen till att de inte nämns är kanske inte att studenterna tyckte att de var svåra att lära sig. Ytterligare en aspekt på svårighetsgraden kan hänga samman med att de grekiska termerna är s.k. kognater (Brenders m. fl. 2011: 383-384), det vill säga de används på svenska också, dock med något annorlunda stavning. Studenterna kan ha kommit i kontakt med dessa kognater i sina svenskstudier under högstadiet/gymnasiet eller utanför skolan.

I svaren från studenterna på kandidat- eller magisternivån (termin 3/5) var det möjligt att inventera vilka termer som nämndes efter att en längre tid förlupit sedan terminologin lärdes in, då de har tagit kurser i sitt andra ämne eller i sin programinriktning efter studierna i engelska. Än en gång bör påpekas att dessa studenter besvarade enkäten per mejl och därmed hade tillgång till hjälpmedel. 
Tabell 2. Fråga 3: Litteraturvetenskapliga termer, studenter på termin 3/5

\begin{tabular}{|l|l|}
\hline $\begin{array}{l}\text { Antal studenter } \\
\text { som nämner } \\
\text { termen }\end{array}$ & Termer \\
\hline 7 & narrative, narrator, narration, unreliable narrator \\
\hline 4 & protagonist \\
\hline 3 & antagonist \\
\hline 2 & allegory, catharsis, ellipsis, genre, imagery, scope, stanza \\
\hline 1 & $\begin{array}{l}\text { alliteration, analepsis, archetype, Bildungsroman, canon, character, climax, } \\
\text { coherence, comedy, contextualized reading, couplet, critical race theory, } \\
\text { defamiliarization, direct discourse/ indirect discourse/ free indirect discourse, } \\
\text { drama, duality, epiphany, flashback/ flash forward, focalization, gender, } \\
\text { hamartia, iambic pentameter, irony, limerick, lyric, metonomy, metaphor, } \\
\text { onomatopoeia, narratology, peripeteia, prolepsis, rhyme, rhythm, run-on } \\
\text { sentence, sarcasm, satire, setting, story, the dramaturgical curve of literature, } \\
\text { theme }\end{array}$ \\
\hline
\end{tabular}

Det är fler termer som endast nämndes av en enstaka student i tabell 2. Det var också stor skillnad i ambitionsnivå då en av studenterna nämnde 32 termer, flera nämnde sju termer och den som nämnde minst antal listade fem termer. Förstaterminsstudenterna nämnde totalt 68 av de 92 olika termer som fanns i undervisningsmaterialet medan kandidat- eller magisterstudenterna nämnde 55 olika termer.

Huruvida respondenterna ansåg att en term var grundläggande eller avancerad kan även betecknas som del av deras uppfattning om termen i fråga. Det var nio termer som alla tillfrågade studenter grupperade som avancerade: literary universal, mimesis, denouement, proscenium arch, hamartia, anagnorisis, anthropomorphism, Aristotelian unity, allusions. Av dessa är sju från gloslistan för dramatik, en är en fransk term, en har latinskt ursprung och fem har grekiskt ursprung. Ett väntat resultat för uppdelningen i avancerade och grundläggande facktermer var att det i regel var grekiska (analepsis, diegesis, anagnorisis, hamartia, mimesis) eller franska facktermer (denouement) som genomgående kategoriserades av studentgrupperna som avancerade, trots att de från latin och grekiska alltså är kognater. Detta kan bero på att betydelsen härrör från teoretiska, filosofiska eller psykologiska resonemang. Några termer kategoriserade magisterstudenterna som grundläggande medan andraterminsstudenterna tyckte att de var avancerade, vilket skulle kunna antyda att magisterstudenterna nu har internaliserat kunskapen. Det gäller följande ord: foreshadowing, homo/heterodiegetic narrator, blocking, homonyms, personification, catastrophe, 4th wall, melody, soliloquy, peripeteia, catharsis, diegesis, abstract reader, analogy, analepsis, allegory, spectacle. I den här kategoriseringen återfinns fyra termer som enbart gäller narrativ, en enbart för poesi och sju enbart för dramatik. Övriga kan användas både för narrativ och poesi. Ur ett lärarperspektiv hade jag inte förväntat mig att termer som homo/heterodiegetic narrator, blocking, soliloquy, peripeteia, catharsis, diegesis, analepsis skulle betraktas som grundläggande, vilket visar på vikten av att studenterna själva fick klassificera termerna.

En del av förstaterminsstudenter hade svårt att definiera flera av termerna när de fyra månader senare skulle klassificera dem i grundläggande och avancerade termer, vilket tyder på att dessa inte lagrats i långtidsminnet (Hultén 2010) utan varit föremål för en instrumentell 
inlärning inför tentamen och sedan glömts bort. Detta kunde noteras eftersom jag var närvarande när de gjorde uppdelningen.

Ett oväntat resultat var att kriteriet de använde när de gjorde uppdelningen inte var ifall de själva kunde termen utan i stället lyftes sådana aspekter fram som hur komplicerad facktermen var att förstå eller förklara. En student föreslog att en term skulle kunna betecknas som grundläggande om folk i allmänhet känner till den och det höll de andra studenterna i den gruppen med om. Vissa termer orsakade diskussion om vilken klassificering som skulle göras och då försökte studenterna antingen övertala varandra eller lät den som var mest kunnig i terminologi avgöra. Ibland avgjorde helt enkelt den student som sorterade lapparna.

\section{Terminologi som studenterna förklarade}

Som tidigare nämnts är det skillnad mellan att på ett ytligt plan lära in en lista av ord och att på ett djupare plan förstå vad begreppen innebär. För att komma åt huruvida studenterna hade förstått olika termer som de hade räknat upp ville jag att de skulle välja en av de listade termerna och beskriva effekten av den termen på läsaren. Något förenklat beskriver litteraturvetenskapliga termer ofta litterära grepp (till exempel bildspråk och personskildring) som författaren använder för att åstadkomma olika effekter i sin text. Termerna kan också vara av teoretisk art för att beskriva narratologiska företeelser och strukturer i den litterära texten såsom berättarteknik och kronologi. Med andra ord var avsikten att de skulle ange hur det litterära greppet i fråga eventuellt kan påverka läsaren när det används i en skönlitterär text (fråga 4). Nu var det inte den verkliga läsaren som jag åsyftade i frågan utan den som Wolfgang Iser kallar den implicita läsaren (1974), vilken är den hypotetiska adressat till texten som kan utläsas ur fiktionen. Litteraturvetare använder gärna detta begrepp för att hålla sig på en abstrakt nivå där fiktionen som konstruktion upprätthålls och därmed undvika att samtalet leder till spekulationer kring författarens eventuella intentioner eller verkliga läsares individuella reaktioner. Jag ville veta ifall studenterna skulle göra kopplingen mellan författarens val av olika litterära grepp och den effekt på den implicita läsaren som detta grepp kan ha. Alla förklaringar som studenterna gav återges i tabell 3 nedan.

Det måste tillstås att de termer som studenterna valde att förklara bör ha varit sådana som de tyckte att de behärskade så svaren avslöjar föga om deras allmänna förståelse av terminologin. Resultat från Christina Dobbs med fleras studie, i vilken gymnasieelevers förståelse av texter i läroböcker i samhällskunskap diskuteras, visar dock att "students were fairly successful at properly defining discipline-specific terms and were doing reasonably well with other discipline-oriented items" (2016: 135). Så det behöver inte enbart bero på den nära förestående tentamen. Det bör noteras att fyra av de totalt 22 olika termerna som förklaras har majoriteten av studentgrupperna klassificerat som avancerade: denouement, catharsis, peripeteia, anagnorisis. En felmarginal ligger i den låga svarsfrekvensen för just den här frågan. Mindre än hälften av förstaterminsstudenter valde att besvara frågan, vilket kan bero på att det upplevdes som arbetskrävande att behöva skriva så mycket för hand i en enkät. Andra orsaker kan vara tidsbrist, svårighet att förstå frågan eller osäkerhet på innebörden. Av de åtta studenterna på termin 3/5 var det dock bara en student som inte skrev någon förklaring och de fyllde också i enkäten digitalt. Den vanligaste termen i materialet, character, lyser med sin frånvaro i svaren, men den närbesläktade termen characterization är samtidigt den flest studenter har valt att förklara. Termerna protagonist och mindstyle är också populära med tre 
studenter vardera och även dessa termer tangerar personskildringens effekt på den implicita läsaren.

\section{Kategorisering av studenternas förståelse av terminologi}

Vad beträffar innebörden av de litterära termerna, visar materialet att de flesta av studenterna som svarade på frågan om effekten på läsaren verkar ha en uppfattning om det litterära grepp de har valt. I nedanstående svar (se tabell 3 och 4) fokuserar studenterna tydligt på litteraturvetenskapen som ämnesspråkligt område. Då frågan gick att tolka på olika sätt har jag kategoriserat studenternas förklaringar i följande tre grupper: effekt på läsaren av en skönlitterär text, analysredskap och elitistiskt/utestängande uttryck.

Tabell 3. Fråga 4: Kategorier av utsagor om effekten på läsaren (termin 1)

\begin{tabular}{|c|c|c|}
\hline $\begin{array}{l}\text { Effekt på läsaren av en } \\
\text { skönlitterär text ( } 21 \text { utsagor) }\end{array}$ & Analysredskap (12 utsagor) & $\begin{array}{l}\text { Elitistiskt/utestängande } \\
\text { uttryck ( } 5 \text { utsagor) }\end{array}$ \\
\hline $\begin{array}{l}\text { characterization } \\
\text { Bringing the character to life. } \\
\text { Allowing the reader to recognize } \\
\text { some of the reasons as to why the } \\
\text { character behaves as he/she does. }\end{array}$ & $\begin{array}{l}\text { characterization } \\
\text { to analyze character of people }\end{array}$ & $\begin{array}{l}\text { heterodiegetic } \\
\text { fancy word for all knowing } \\
\text { character }\end{array}$ \\
\hline $\begin{array}{l}\text { characterization } \\
\text { It can make the reader relate to a } \\
\text { certain character }\end{array}$ & $\begin{array}{l}\text { characterization } \\
\text { understand the text better }\end{array}$ & $\begin{array}{l}\text { anagnorisis } \\
\text { Greek words make you } \\
\text { more confused than you } \\
\text { were before }\end{array}$ \\
\hline $\begin{array}{l}\text { characterization } \\
\text { As a reader we get a better } \\
\text { understanding and feel connected } \\
\text { to the character }\end{array}$ & $\begin{array}{l}\text { characterization } \\
\text { can see in depth how the } \\
\text { character is effected throughout } \\
\text { the plot }\end{array}$ & \\
\hline $\begin{array}{l}\text { protagonist } \\
\text { empathy }\end{array}$ & $\begin{array}{l}\text { protagonist } \\
\text { doesn't have to be the good guy }\end{array}$ & \\
\hline $\begin{array}{l}\text { protagonist } \\
\text { The reader gets an idea of who the } \\
\text { main character is. }\end{array}$ & $\begin{array}{l}\text { mindstyle } \\
\text { understand the author }\end{array}$ & \\
\hline $\begin{array}{l}\text { mindstyle } \\
\text { gives a more in-depth insight for } \\
\text { the character and creates } \\
\text { understanding for their actions. }\end{array}$ & $\begin{array}{l}\text { mindstyle } \\
\text { the point of view of the } \\
\text { character }\end{array}$ & \\
\hline $\begin{array}{l}\text { mindstyle } \\
\text { the effect it has on the reader. }\end{array}$ & $\begin{array}{l}\text { denouement } \\
\text { It eases up and puts everything } \\
\text { into order. Delivers an ending } \\
\text { that is left open or satisfying. }\end{array}$ & \\
\hline $\begin{array}{l}\text { peripeteia } \\
\text { A heightening of tension, will the } \\
\text { hero recover from the setback? }\end{array}$ & $\begin{array}{l}\text { climax } \\
\text { may open up a deeper } \\
\text { understanding of the book's plot }\end{array}$ & \\
\hline $\begin{array}{l}\text { peripeteia } \\
\text { An increased feeling of either } \\
\text { empathy with a character they } \\
\text { relate too or one of }((\mathrm{xxx})) \text { with a } \\
\text { character they dislike }\end{array}$ & $\begin{array}{l}\text { Setting is both the time-period } \\
\text { but also the environment }\end{array}$ & \\
\hline
\end{tabular}




\begin{tabular}{|c|c|c|}
\hline $\begin{array}{l}\text { denouement } \\
\text { The reader will have an idea about } \\
\text { the end }\end{array}$ & $\begin{array}{l}\text { point of view } \\
\text { It makes it clear to readers how } \\
\text { a story is told }\end{array}$ & \\
\hline $\begin{array}{l}\text { denouement } \\
\text { It helps the reader digest the } \\
\text { events. }\end{array}$ & $\begin{array}{l}\text { foreshadowing } \\
\text { gives a hint of what is yet to } \\
\text { come. Also, gives a hint of the } \\
\text { genre if that is not told. }\end{array}$ & \\
\hline $\begin{array}{l}\text { catharsis } \\
\text { displays the intense effect in a } \\
\text { clear and understandable way }\end{array}$ & $\begin{array}{l}\text { diction } \\
\text { helps the reader focus on } \\
\text { different characters' language } \\
\text { and what it says about the } \\
\text { character }\end{array}$ & \\
\hline $\begin{array}{l}\text { catastrophe } \\
\text { Awakens otherwise concealed, } \\
\text { dark emotions }\end{array}$ & $\begin{array}{l}4^{\text {th }} \text { wall } \\
\text { Movie- or TV-based }\end{array}$ & \\
\hline $\begin{array}{l}\text { climax } \\
\text { makes the reader want to keep } \\
\text { reading }\end{array}$ & $\begin{array}{l}\text { focalization } \\
\text { If you do not know what it } \\
\text { means, you will at least think it } \\
\text { is something about focus }\end{array}$ & \\
\hline $\begin{array}{l}\text { metaphor } \\
\text { gets the reader to think for } \\
\text { themselves }\end{array}$ & & \\
\hline $\begin{array}{l}\text { setting } \\
\text { it helps the reader understand the } \\
\text { context of the story and visualize. }\end{array}$ & & \\
\hline $\begin{array}{l}\text { imagery } \\
\text { gives the reader a chance to } \\
\text { interpret the story in a unique way }\end{array}$ & & \\
\hline $\begin{array}{l}\text { antagonist } \\
\text { irritation }\end{array}$ & & \\
\hline $\begin{array}{l}\text { symbolism } \\
\text { urges the reader to read between } \\
\text { the lines }\end{array}$ & & \\
\hline $\begin{array}{l}\text { comic relief } \\
\text { Gives the reader a moment to } \\
\text { "calm down" }\end{array}$ & & \\
\hline $\begin{array}{l}\text { story } \\
\text { If it's a good story the reader will } \\
\text { get much more into the book }\end{array}$ & & \\
\hline
\end{tabular}


Tabell 4. Fråga 4: Kategorier av utsagor om effekten på läsaren (termin 3/5)

\begin{tabular}{|c|c|c|}
\hline Effekt på läsaren (4 utsagor) & Analysredskap (2 utsagor) & $\begin{array}{l}\text { Elitistiskt/utestängande } \\
\text { uttryck ( } 2 \text { utsagor) }\end{array}$ \\
\hline $\begin{array}{l}\text { protagonist } \\
\text { You have a main character to } \\
\text { follow and like or not like in a } \\
\text { book or a short text. You have } \\
\text { someone to identify with or not } \\
\text { but you can look at the good side } \\
\text { of the plot. }\end{array}$ & $\begin{array}{l}\text { duality } \\
\text { As soon as the readers know } \\
\text { what 'duality' means when } \\
\text { reading literature, the text they } \\
\text { read becomes more } \\
\text { interpretable. For example, the } \\
\text { readers can see differences } \\
\text { between characters, places, } \\
\text { objects and so on. Also, with the } \\
\text { help of this term and all the } \\
\text { other ones, the reader can } \\
\text { analyse a text better. }\end{array}$ & $\begin{array}{l}\text { antagonist } \\
\ldots \text {. Furthermore, it is one of } \\
\text { those words that makes you } \\
\text { sound smart }\end{array}$ \\
\hline $\begin{array}{l}\text { in medias res } \\
\text { Interest and excitement }\end{array}$ & $\begin{array}{l}\text { gender } \\
\ldots \text {. . the reader becomes more } \\
\text { aware of gender structures and } \\
\text { issues }\end{array}$ & $\begin{array}{l}\text { metaphor } \\
\text { If they can identify the } \\
\text { metaphor so to say. }\end{array}$ \\
\hline $\begin{array}{l}\text { alliteration } \\
\text { Personally I felt sentences that } \\
\text { contained alliteration made me } \\
\text { remember them better, they made } \\
\text { a different impression }\end{array}$ & & \\
\hline $\begin{array}{l}\text { metaphor } \\
\text { If used correctly and it fits nicely } \\
\text { into the text, the reader might } \\
\text { recognize the situation }\end{array}$ & & \\
\hline $\begin{array}{l}\text { antagonist } \\
\text { The word itself sounds evil and } \\
\text { the reader will therefor also think } \\
\text { that the character is evil by just } \\
\text { hearing the word. }\end{array}$ & & \\
\hline
\end{tabular}

Tabellerna visar att de flesta studentutsagor handlar om effekten på den implicita läsaren, hur denna påverkas av det litterära greppet när det används av författaren, vilket var avsikten med frågan. Många studenter kommenterar hur personskildringen stärker läsarens identifikationsförmåga vilket är tydligt i följande påståenden: "Bringing the character to life. Allowing the reader to recognize some of the reasons as to why the character behaves as he/she does", "It can make the reader relate to a certain character", "As a reader we get a better understanding and feel connected to the character", "empathy" och "You have a main character to follow and like or not like in a book or a short text. You have someone to identify with or not but you can look at the good side of the plot." Den amerikanska forskaren i kognitiv poetik, Suzanne Keen, konstaterar i monografin Empathy and the Novel att "the very fictionality of novels predisposes readers to empathize with characters" (2007: 4). Studenterna har alltså identifierat en reaktion på romanläsning som enligt Keen finns inbyggd i fiktionen. Att studenterna fokuserar på läsarens upplevelse skulle också kunna tyda på att de har tagit till sig 
det sätt att se på läsning som förespråkas inom reader response (Rosenblatt 1978; 1995) och som fått genomslag i undervisning på lägre stadier i Sverige genom den brittiske författaren Aidan Chambers populära bok Tell Me: Children, Reading and Talk (1996).

Vad beträffar terminologi som analysredskap förväntade jag mig att förstaterminsstudenterna skulle uppfatta att termerna var viktiga med tanke på att dessa skulle tenteras muntligt och användas i den skriftliga examinationsuppgiften och därmed i två fall kunde påverka deras chanser till godkänt betyg på kursen. Denna uppfattning stärks av formuleringar i uppgiftsinstruktionen och betygskriterierna (se bilaga 3 och 4). Följande studentkommentarer indikerar att det finns en medvetenhet om nyttan med terminologin för att kunna utföra de moment som förväntas inom ämneslitteraciteten: "to analyze character of people", "understand the text better", "may open up a deeper understanding of the book's plot", "helps the reader focus on different characters' language and what it says about the character" och "As soon as the readers know what 'duality' means when reading literature, the text they read becomes more interpretable. For example, the readers can see differences between characters, places, objects and so on. Also, with the help of this term and all the other ones, the reader can analyse a text better." De här studenterna formulerar tydligt termernas funktion som analysredskap vilket illustrerar ett av syftena med litteraturvetenskapens ämneslitteracitet.

Cynthia Shanahan efterlyser denna förmåga när hon skriver: "Students, then, need to learn how to engage in practices that will help them solve specific problems with disciplinary texts" (2013: 94). Eftersom mina informanter påtalar att termerna är nödvändiga för att kunna utföra de uppgifter som ingår inom ämnesområdet skulle de teoretiska begreppen kunna ses som en stödstruktur som hjälper dem att identifiera passager i den litterära texten som kan behandlas i analysen. Att teorin fungerar på detta sätt uttrycks av studenten som skriver om genus: ". . . the reader becomes more aware of gender structures and issues." Teorin möjliggör en annan typ av läsning än den identifikatoriska, genom att studenten kan undersöka hur genusfrågor gestaltas i texten med kritisk distans. När studenterna förmår definiera de litteraturvetenskapliga termerna träder de in i ämneslitteraciteten genom att de blir kapabla att uttala sig om skönlitteraturens funktion och struktur, vilket blir tydligt i följande studentutsagor: "It eases up and puts everything into order. Delivers an ending that is left open or satisfiable;" "It makes it clear to readers how a story is told" och "gives a hint of the genre if that is not told." Studenternas röster ger här uttryck för ett annat sätt att se på litteratur än den vardagliga där läsning ofta ses som underhållning eller tidsfördriv. Här framkommer att ämneslitteraciteten upplevs som positiv av flera respondenter.

En annan slutsats av materialet är att ämnesspråkets signalfunktion för talarens kulturella kapital tycks uppenbar för några av studenterna (jfr Bourdieu 1986: 47). Två olika studenter konstaterar självmant i sina svar att användandet av termen har en statushöjande effekt: "fancy word for all knowing narrator" och "it is one of those words that makes you sound smart." Två andra studenter kommenterar likaledes oombett vad som skulle kunna tolkas som en utestängande effekt: "Greek words make you more confused than you were before" och "If they can identify the metaphor so to say." Underförstått i dessa kommentarer är tesen att ett visst sätt att tala eller skriva fungerar som kulturellt kapital. Funktionen skulle kunna vara att språket blir ett sorteringsinstrument som stänger ute de människor som inte har socialiserats in i diskursgemenskapen. Draget till sin spets innebär detta enligt Bourdieu att det kulturella kapitalet kan fungera som ett vapen i klasskampen: "the agents wield strengths and obtain 
profits proportionate to their mastery of this objectified [cultural] capital" (1986: 50). Även om signalfunktionen för kulturellt kapital endast uttrycktes av ett fåtal studenter i undersökningen anser jag att det är ett intressant resultat just därför att den inte efterfrågades i klartext.

Som studenternas utsagor visar kan ämneslitteraciteten behöva problematiseras. Tillhörighet med en viss ämnesspråklig gemenskap markeras när man använder litteraturvetenskapliga termer. Samtidigt kan människor i omgivningen känna sig okunniga eller utanför. En ytterligare tolkning av dessa kommentarer kan vara att informanterna inte identifierar sig som medlemmar av disciplinen. Som utomstående ser de litteraturvetenskapliga termer som uttryck för ämneslitteracitet i det avseendet att de tydligt skiljer sig från vardagligt språkbruk.

\section{Attityder till terminologi}

Det uppenbara sättet att göra studenternas röster hörda i studien var givetvis att direkt fråga dem hur de såg på ämnesspråk i form av litteraturvetenskapliga termer (enkätfråga 1, 5, 6, 7 och 8). Fråga 1 (What is your opinion of literary terminology?) undersöker studenternas uppfattningar och de flesta tycks ense om att terminologi är ett användbart redskap för att analysera litteratur, 39 studenter (57\%) på termin 1 valde det svarsalternativet. 27 studenter (40 \%) valde det neutrala svarsalternativet, att det kan vara användbart om man är intresserad av litteratur och en student uttryckte en negativ attityd. I kommentarerna framträder en något mer nyanserad bild. En student menade att det är fullt möjligt att skriva analyser utan att använda termerna. En annan kommentar var att man inte måste använda termerna men att det är tids - och utrymmesbesparande att göra det. Det kan också bero på vem läsaren är. Endast om läsaren kan förväntas känna till termerna är det lämpligt att använda dem. Termerna ska heller inte användas för sakens egen skull utan bara om det passar i texten. Vikten av att enbart använda termerna med människor som också känner till dem, att termer är nyttiga redskap och att termerna redan hade lärts in framkom också i kommentarerna. På kandidat/magisternivån (termin 3/5) svarade sju studenter på fråga 1 (What is your opinion of literary terminology?) att terminologi är ett användbart redskap för att analysera litteratur. En student valde både det positiva och det negativa alternativet, men ingen lämnade en kommentar.

När det gäller frågan om studenterna trodde att de skulle använda termerna de lärt sig i framtiden svarade $28(43 \%)$ av förstaterminsstudenterna att de kommer att få användning av termerna i framtiden, 33 studenter $(51 \%)$ trodde att de kanske skulle göra det, nio (13\%) studenter trodde inte att de skulle få användning av litteraturvetenskapliga termer (fråga 5). I de här svaren finns en större spridning: mindre än hälften av studenterna är positiva, mer än hälften är osäkra och drygt en tiondel är negativa. Nyttan av termerna tycks mer oklar för studenterna när det gäller kopplingen till framtida yrkesutövning, såvida de inte tänker sig en framtid såsom författare eller lärare.

På termin 3/5 svarade fem av studenterna att de kommer att få användning av termerna i framtiden men tre respondenter var osäkra. I kommentarerna syns en tydlig koppling till yrkesverksamhet då ett par av lärarstudenterna nämnde att de kommer att få användning av terminologin i sin undervisning. Majoriteten av studenterna på termin 3/5 var positiva eller osäkra och ingen var negativ till skillnad från förstaterminsstudenterna.

För att ta reda på ifall studenterna stött på termerna utanför akademin undrade jag om de hade träffat på termerna i sitt privatliv (fråga 6). Av förstaterminsstudenterna svarade 42 
studenter ja (65\%), 12 studenter: vet ej (19\%), nio studenter: nej (14\%) och en student: inget av alternativen (2\%). Eftersom en majoritet av studenterna kände igen termerna från andra sammanhang kan det tänkas att de redan till stor del behärskade ämnesspråket. Det kan dock gälla andra betydelser av termerna än de litteraturvetenskapliga och då faller kunskapen inte in under det ämnesspråk som diskuteras i den här studien. Visserligen kan det upplevas som relevant att lära sig termer om man känner till att de används mer generellt i samhället, men det indikerar också att termerna inom litteraturvetenskap inte enbart är ämnesspecifika.

Vad gäller ifall studenterna tyckte att det var nödvändigt med litteraturvetenskapliga termer vid skrivande av självständiga arbeten (fråga 7), svarade 52 av förstaterminsstudenterna (80 $\%)$ : ja, fem studenter ( $8 \%$ ) svarade: vet ej, sju studenter (11\%) svarade: nej och två studenter (3\%): inget av alternativen. Sju av åtta studenter på termin 3/5 svarade att termer behövs i litteraturvetenskapliga analyser (fråga 7). Den student som svarade att hen inte visste om det är nödvändigt kommenterade att det beror på vad man analyserar i den litterära texten. Det är tänkbart att de mer allmänna litteraturvetenskapliga termerna mest förknippas med ämneslitteracitet under den första terminen då det stoffet ska examineras och fokus ligger på närläsning och allmän narratologi. Under senare terminer skiftar fokus mot det teoretiska ramverk som varje student väljer individuellt för sin analys i det självständiga arbetet, vilket har sina centrala begrepp och då är det kanske de termerna som framträder som ämneslitteracitet i stället.

Sammanfattningsvis visar resultaten från enkäten att de flesta studenter tycker att litteraturvetenskapliga termer utgör en del av ämnesspråket. En klar majoritet av kandidat- och magisterstudenterna uppger att terminologin fungerar som nödvändiga redskap och likaså mer än hälften av förstaterminsstudenterna. Begreppens användbarhet vid akademiskt skrivande är det snarare förstaterminsstudenterna som är övertygade om, medan en knapp majoritet av studenterna på termin $3 / 5$ håller med. En anledning till att de vill tillägna sig litteraturvetenskaplig terminologi kan vara att de ser det som ett delmoment på vägen för att kunna lyckas med sitt akademiska skrivande. Härigenom kan de röra sig från ett vardagligt sätt att tala om litteratur till en vetenskaplig och analyserande ansats. Att erövra konsten av akademiskt skrivande är en process som kan ta flera år att bemästra (Cumming 2006: 161). Att det rör sig om en långsam utveckling ger dock en möjlighet för universitet att kompensera för tidigare brister i socialisationsprocessen genom till exempel generös timtilldelning åt handledare samt skrivarverkstäder i bibliotekens regi.

Bilden av ämnesspråk som sorteringsverktyg (Bourdieu 1986: 47-51) lyser i stort sett med sin frånvaro i den del av materialet som handlar om studenternas uppfattningar. Två studenter noterade dock vikten av mottagaranpassning vid användning av terminologi. Först i samband med deras föreställningar om termer rent allmänt i frågan om vad de ansåg om litteraturvetenskapliga termer: "But, the person you are talking to or who is reading needs to know what the terms means to understand, and some of them is quite hard to guess what they could mean." Och sedan i samband med nyttan av termer vid författandet av skriftliga uppgifter: "Depends on the intended audience and if they are familiar with the terms." Det förhållningssätt som dessa kommentarer uppvisar verkar mer spegla en omsorg om andra deltagare i samtalet eller läsare av studentens text än den rädsla att verka högfärdig som respondenten i Lees och Kramers studie gav uttryck för (2013: 27). Vissa informanter uppvisar alltså en medvetenhet om att språkbruket kan ha en utestängande effekt. 


\section{Avslutning}

Syftet med den här studien var att låta studenternas röster komma fram i det didaktiska samtalet om ett undervisningsmoment på en delkurs i litteraturvetenskap inom engelskämnet. Jag har undersökt vilka litteraturvetenskapliga termer som studenterna räknade upp, hur de förklarade några av termerna och vilka uppfattningar om terminologi de hade. En tolkning av resultatet är att studenterna åtminstone i någon mån såg sig som deltagare i ämneslitteraciteten. Studenterna nämnde en mängd termer som behövs för att kunna tala och skriva som en litteraturvetare. Ett förvånande resultat är att termen character endast nämns av två studenter på termin $1 \mathrm{och}$ av en student på termin 3/5. En förklaring kan vara att det är en så pass grundläggande term att studenterna kanske inte kom att tänka på den. Den imponerande variationen av termer som listades kan tolkas som att studenterna anser att det är viktigt att lära sig termerna. Dessutom gav ungefär hälften av studenterna uttryck för ämnesspråklig kompetens genom att förklara vad ett begrepp innebär när det används, till exempel i en litterär text. Flertalet av förklaringarna handlade om läsarens förmåga till identifikation eller att termer kan användas som analysredskap. Ett mindre framträdande resultat var att ämnesspråkets funktion som indikator på kulturellt kapital visades i att ett par studenter spontant kommenterade att i synnerhet de grekiska och franska termerna fungerar som högstatusmarkörer eller kan ha en utestängande effekt. Vad avser studenternas uppfattningar tycks de flesta ändå vara överens om nyttan med termerna.

Resultatet av studien bör naturligtvis betraktas med försiktighet. Med tanke på att förstaterminsstudenterna listade vilka termer de hade lärt sig veckan före en tentamen på detta innehåll är det förståeligt ifall de hade memorerat en stor mängd vid det tillfället. Kandidatoch magisterstudenterna (termin 3/5) besvarade enkäten via mejl vilket innebär att de kunde använda hjälpmedel för att hitta termer och definitioner.

För att minska effekten av problematiska aspekter inom ämneslitteraciteten föreslår jag att ämnesspråk medvetet skulle kunna presenteras på ett sådant sätt för nya studenter att utestängningsmekanismen minskar och att de i stället känner sig välkomnade in i ämneslitteraciteten. Ur ett demokratiperspektiv och med tanke på satsningar på breddad rekrytering skulle universitetslärare kunna sträva efter att designa kurser där studenterna ges rikliga tillfällen att utveckla de färdigheter som ska examineras genom inkluderande undervisningsmetoder. I rollspel eller vid diskussioner av fallstudier kan risken att ämnesspråket får en utestängande effekt eventuellt minska eftersom det blir tillåtet att pröva och använda olika röster genom det aktiva deltagandet $\mathrm{i}$ ämneslitteraciteten. I en sådan lärandesituation är det klart uttalat att studenterna har lov att experimentera med nya språkbruk och att syftet inte är att uppvisa tidigare erövrade kunskaper.

Ett sätt att didaktiskt problematisera momentet terminologi skulle kunna vara att tillsammans med studenterna kritiskt granska vetenskapliga artiklar utifrån inriktning och användning av termer. Studenterna kunde undersöka ifall termerna används som redskap för att åskådliggöra författarens bruk av olika litterära grepp, textens intrikata struktur eller för att diskutera litteraturens effekt på den implicita läsaren. De kunde också analysera om terminologi huvudsakligen används i de inledande avsnitten för att signalera teoretisk hemvist eller om det snarare är ett fokus på applicering av teori i analysen. 
Också från en ekonomisk synvinkel, i tider av vikande studentpopulationer, kan sättet som studenter introduceras till ämnesspråk i synnerhet och universitetsstudier i allmänhet vara ett område som är värt att undersöka vidare. Går det att avdramatisera ämneslitteracitetens komplexitet och synliggöra dess text- och talstrategier så att studenterna stegvis kan närma sig sättet att tala om ämnet på expertvis, vilket skulle underlätta insocialiseringen i akademiska studier? Om ämneslitteracitet dessutom tydligt framställs som en uppsättning nyttiga redskap som gagnar studentens förmåga att utföra viktiga uppgifter utan implikationen att det nya språkbruket måste ersättas eller trängas bort andra sätt att tala, kunde socialiseringsprocessen underlättas ytterligare.

Ytterligare ett uppslag för framtida forskning vore att studera i vilken grad litteraturvetenskapliga termer verkligen fungerar som analytiska verktyg i studenttexter på olika nivåer i utbildningssystemet och inte som pliktskyldiga inflikningar för sakens egen skull. Även olika sätt som universitetslärare arbetar med att utforma utvecklingsgången till ämneslitteracitet för sina studenter vore spännande att undersöka närmare.

\section{Referenser}

Angelo, Thomas A. \& Cross, Patricia K. (1993), Classroom Assessment Techniques: A Handbook for College Teachers. 2:a uppl. San Francisco: Jossey-Bass, a Wiley Imprint.

Bergh Nestlog, Eva (2019), "Ämnesspråk - en fråga om innehåll, röster och strukturer i ämnestexter", HumaNetten 42: 9-30.

Bourdieu, Pierre (1986), "The Forms of Capital", i John G. Richardson (red) Handbook of Theory of Research for the Sociology of Education. Westport: Greenwood Press, s. 241-258. https://faculty.georgetown.edu/irvinem/theory/Bourdieu-Forms-of-Capital .pdf. Nedladdad 2018-06-13.

Brenders, Pascal, Van Hell, Janet G., \& Dijkstra, Ton (2011), "Word Recognition in Child Second Language Learners: Evidence from Cognates and False Friends", Journal of Experimental Child Psychology, 109(4): 383-396.

Broady, Donald, Höglund, Carl-Magnus \& Wigerfelt, Christer (2007), “Den dolda läroplanen”, Krut: Kritisk utbildningstidskrift, 127(3): 102-110. Göteborg: Krut.

Bryman, Alan (2016), Social Research Methods. 5:e uppl. Oxford: Oxford University Press.

Chambers, Aidan (1996), Tell me: Children, Reading, and Talk. York: Stenhouse.

Coxhead, Averil (2000), “A New Academic Word List”, TESOL Quarterly, 34(2): 213-238. Se också själva listan: https://www.victoria.ac.nz/lals/resources/academicwordlist /information. Nedladdad 2018-06-13.

Cumming, Alister (red) (2006), Goals for Academic Writing: ESL Students and their Instructors. Philadelphia: John Benjamins Publishing Company.

Daniel, Johnnie (2011), Sampling Essentials: Practical Guidelines for Making Sampling Choices. London: SAGE.

Denscombe, Martyn (2014), The Good Research Guide: For Small-Scale Social Research Projects. 5:e uppl. Maidenhead: McGraw-Hill/Open University Press.

Dobbs, Christina L., Ippolito, Jacy, \& Charner-Laird, Megin (2016), "Layering Intermediate and Disciplinary Literacy Work: Lessons Learned From a Secondary Social Studies Teacher Team", Journal of Adolescent \& Adult Literacy, 60(2): 131-139.

Dodou, Katarina (2015), "Mångfald bortom identifikationer: studentpopulationens diversifiering och vetenskapens arbetssätt", Högre Utbildning 5(3): 175-187. 
Draper, Roni Jo \& Wimmer, Jennifer J. (2015), “Acknowledging, Noticing, and Reimagining Disciplinary Instruction: The Promise of New Literacies for Guiding Research and Practice in Teacher Education", Action in Teacher Education 37(3): 251-264.

Ek, Anne-Charlotte, Ideland, Malin, Jönsson, Sandra \& Malmberg, Claes (2011), "Högskoleutbildning i spänningsfältet mellan akademisering och marknadifiering", Proceedings: Att leda högre utbildning, s. 1-5.

Elmgren, Maja \& Henriksson, Ann-Sofie (2018), Academic teaching. 3:e uppl. Lund: Studentlitteratur.

Freire, Paulo (1977), Utbildning för befrielse i översättning av Fredrik Rodhe. Stockholm: Gummesson.

Gardner, Janet E. \& Diaz, Joanne (2017), Reading and Writing about Literature: A Portable Guide. 4:e uppl. Boston: Bedford/St. Martin's.

Garrett-Petts, William F. (2013), Writing about Literature: A Guide for the Student Critic. 2:a uppl. Ontario: Broadview Press.

Greenwood, Davydd J., \& Levin, Morten (2007), Introduction to Action Research: Social Research for Social Change. 2:a uppl. Thousand Oaks: SAGE Publications.

Graff, Gerald (2000), "Disliking Books at an Early Age", i David H. Richter (red), Falling into Theory: Conflicting Views on Reading Literature. 2:a uppl. Boston: Bedford/St. Martin's, s. 41-48.

Hart, Betty \& Risley, Todd R. (1995), Meaningful Differences in the Everyday Experiences of Young American Children. Baltimore: Brookes.

Hjalmarsson, Jan, Nikolaidou, Zoe, Sköldvall, Kajsa, \& Heinonen Eklund, Maria (2017), "'Fan va grymma vi är' - effekter av ämnesintegrerad undervisning i akademiskt skrivande", Språk och Normer. Language and Norms. Rapport från ASLA:s symposium, Uppsala universitet 21-22 april 2016, s. 37-44.

Hultén, Anne, Laaksonen, Hannu, Vihla, Minna, Laine, Matti, \& Salmelin, Riitta (2010), "Modulation of Brain Activity after Learning Predicts Long-Term Memory for Words", The Journal of Neuroscience: The Official Journal of the Society for Neuroscience, 30(45): 15160-15164.

Hållsten, Stina (2017), "Stöttning av skrivande i ett digitalt diskussionsforum: Kan den digitala lärplattformens kursdesign utvecklas genrepedagogiskt?", Högre Utbildning, 7(1): 1328.

Iser, Wolfgang. (1974, 1990), The Implied Reader: Patterns of Communication in Prose Fiction from Bunyan to Beckett. Baltimore: Johns Hopkins University Press.

Johansson, Britt, \& Sandell Ring, Anniqa (red) (2015), Låt språket bära: Genrepedagogik $i$ praktiken. 4. uppl. Stockholm: Hallgren \& Fallgren.

Keen, Suzanne (2007), Empathy and the Novel. Oxford: Oxford University Press.

Kursplan för 1EN100 HT2017 vid Linnéuniversitetet, institutionen för Språk. https://lnu.se/systemsidor/utbildningsplaner/?id=1EN100. Nedladdad 2018-11-29.

Lee, Carol D., \& Goldman, Susan R. (2015), “Assessing Literary Reasoning: Text and Task Complexities", Theory into Practice, 54(3): 213-227.

Lee, Elizabeth M. \& Kramer, Rory (2013), "Out with the Old, in with the New? Habitus and Social Mobility at Selective Colleges", Sociology of Education, 86(1): 18-35. doi: $10.1177 / 0038040712445519$.

Lutas, Liviu (2014), "Teori i litteraturundervisning på gymnasiet: Tre klassrumsexempel”, i Anders Persson \& Roger Johansson (red), Vetenskapliga perspektiv på lärande, undervisning och utbildning $i$ olika institutionella sammanhang: utbildningsvetenskaplig forskning vid Lunds universitet. Lund: Lund University Press, s. 127-144. 
Martinsson, Bengt-Göran (2015), "Litteraturdidaktik som litteraturvetenskap", i Maria Jönsson \& Anders Öhman (red), Litteratur och läsning: Litteraturdidaktikens nya möjligheter. Lund: Studentlitteratur, s. 171-190.

Reynolds, Todd \& Rush, Leslie S. (2017), "Experts and Novices Reading Literature: An Analysis of Disciplinary Literacy in English Language Arts", Literacy Research and Instruction 56(3): 199-216.

Rosenblatt, Louise M. (1978), The Reader, the Text, the Poem: Transactional Theory of the Literary Work. Carbondale: Southern Illinois University Press.

Rosenblatt, Louise M. (1995), Literature as Exploration. 5:e uppl. New York: Modern Language Association of America.

Shanahan, Cynthia Hynd (2013), "What Does It Take? The Challenge of Disciplinary Literacy", Journal of Adolescent \& Adult Literacy, 57(2): 93-98.

Shanahan, Cynthia Hynd \& Shanahan, Timothy (2014), "The Implications of Disciplinary Literacy", Journal of Adolescent \& Adult Literacy, 57(8): 628-631.

Siebert, Daniel K., Draper, Roni Jo, Barney, Daniel, Broomhead, Paul, Grierson, Sirpa, Jensen, Amy P., Nielson, Jennifer, Nokes, Jeffery D., Shumway, Steven \& Wimmer, Jennifer (2016), "Characteristics of Literacy Instruction that Supports Reform in Content Area Classrooms", Journal of Adolescent \& Adult Literacy, 60(1): 25-33.

Soria, Krista \& Stebleton, Michael (2013), "Social Capital, Academic Engagement, and Sense of Belonging among Working-Class College Students", College Student Affairs Journal, 31(2): 139-153.

SOU 1992: 1434 Riksdagsförvaltningen (1992), Högskolelag. https://www.riksdagen.se /sv/dokument-lagar/dokument/svensk-forfattningssamling/hogskolelag-19921434_sfs1992-1434. Nedladdad 2018-12-07.

Stephens, Nicole M., Markus, Hazel Rose \& Fryberg, Stephanie A. (2012), "Social Class Disparities in Health and Education: Reducing Inequality by Applying a Sociocultural Self Model of Behavior", Psychological Review, 119(4): 723-744.

Tegnér, Esaias (1847-1851), Samlade skrifter. Tredje bandet, 160. http://runeberg.org /tegnersskr/3/0168.html. Nedladdad 2019-02-17.

Thompson, Clive (2019), "The Secret History of Women in Coding", The New York Times Magazine, 13 feb. https://www.nytimes.com/2019/02/13/magazine/women-codingcomputer-programming.html. Nedladdad 2019-02-16.

Vetenskapsrådet (2017), God forskningssed. Stockholm. https://www.vr.se/analys-ochuppdrag/vi-analyserar-och-utvarderar/alla-publikationer/publikationer/2017-08-29-godforskningssed.html. Nedladdad 2019-02-01.

West, Michael (1953), A General Service List of English Words. London: Longman.

Wilder, Laura (2012), Rhetorical Strategies and Genre Conventions in Literary Studies: Teaching and Writing in the Disciplines. Carbondale and Edwardsville: Southern Illinois UP.

Wilder, Laura (2002), "Get Comfortable With Uncertainty': A Study of the Conventional Values of Literary Analysis in an Undergraduate Literature Course", Written Communication, 19(1): 175-221. 


\section{Bilagor}

Bilaga 1: Utdrag från kursplan för 1EN100 Engelska, allmän kurs, grundkurs, 30 högskolepoäng

\section{Delkurs 3. Introduktion till engelskspråkig litteratur, 10 högskolepoäng}

Efter avslutad delkurs ska den studerande kunna:

- redogöra för grundläggande litteraturvetenskaplig terminologi samt tillämpa denna

- på litterära texter i både muntliga och skriftliga uppgifter,

- orientera sig inom litteraturvetenskap som forskningsområde,

- jämföra olika litterära genrer och former,

- kritiskt granska syfte och metod i litteraturvetenskapliga texter,

- reflektera över hur användbara olika teoretiska verktyg är vid analys av en

- specifik text

\section{Innehåll}

Narrativ och dramatik, $5 \mathrm{hp}$

Delkursen presenterar litteraturvetenskapliga verktyg för att analysera olika genrer inom epik och dramatik. Studenten utforskar narrativa tekniker i engelskspråkiga romaner, noveller och dramer. Narratologiska och andra teoretiska perspektiv tillämpas och betraktas från olika synvinklar beträffande vilka aspekter som därmed synliggörs i litterära texter. Studenten undersöker även hur litterära analyser påverkas av sociala och kulturella kontexter. 
Bilaga 2: Glossary drama 1EN100 Fall 2017

\begin{tabular}{|c|c|c|}
\hline & concept & definition \\
\hline 1 & tragedy & $\begin{array}{l}\text { "A play in which the plot moves from relative stability to death or } \\
\text { other serious sorrow for the protagonist" (Gardner and Diaz 207). }\end{array}$ \\
\hline 2 & plot & "The action that takes place within the play" (Gardner and Diaz 200). \\
\hline 3 & characterization & $\begin{array}{l}\text { "the process by which writers and actors make a character distinct } \\
\text { and believable to an audience" (Gardner and Diaz 188). }\end{array}$ \\
\hline 4 & subplot & $\begin{array}{l}\text { "A secondary plot that exists in addition to the main plot and involves } \\
\text { the minor characters" (Gardner and Diaz 206). }\end{array}$ \\
\hline 5 & diction & $\begin{array}{l}\text { Through their accent, dialect, word choice, mood, and attitude, } \\
\text { characters may reveal important aspects about their personality and } \\
\text { background (Gardner and Diaz 115). }\end{array}$ \\
\hline 6 & peripeteia & $\begin{array}{l}\text { "A reversal or change of fortune for a character, for better or worse." } \\
\text { (Gardner and Diaz 200). }\end{array}$ \\
\hline 7 & spectacle & $\begin{array}{l}\text { "the costumes, the actors' movements, the sets, the lights" (Gardner } \\
\text { and Diaz 116) }\end{array}$ \\
\hline 8 & dialogue & $\begin{array}{l}\text { "the verbal exchanges between the characters. Since there can be no } \\
\text { description or commentary on the action as there is in novels, the } \\
\text { dialogue must tell the whole story" (Jacobus 20). }\end{array}$ \\
\hline 9 & stage directions & $\begin{array}{l}\text { "Written instructions in the script telling actors how to move on the } \\
\text { stage or how to deliver a particular line" (Gardner and Diaz 205). }\end{array}$ \\
\hline 10 & setting & $\begin{array}{l}\text { "must either be displayed onstage or alluded to through the } \\
\text { characters" words" (Gardner and Diaz 116). }\end{array}$ \\
\hline 11 & playwright & The author of a play \\
\hline 12 & props & $\begin{array}{l}\text { "Any movable objects, beyond scenery and costumes, used in the } \\
\text { performance of a play" (Gardner and Diaz 202). }\end{array}$ \\
\hline 13 & director & $\begin{array}{l}\text { The person in charge of the artistic vision of the production and the } \\
\text { one who tells the actors what to do and how to do it. }\end{array}$ \\
\hline 14 & play script & the text of a play \\
\hline 15 & satire & $\begin{array}{l}\text { "A work, or manner within a work, employing comedy and irony to } \\
\text { mock a particular human characteristic or social institution. } \\
\text { Generally, a satirist wants the audience not only to laugh but also to } \\
\text { change its opinions or actions" (Gardner and Diaz 203) }\end{array}$ \\
\hline 16 & upstage & $\begin{array}{l}\text { "As a noun or an adjective, the part of the stage farthest from the } \\
\text { audience, at the back of the playing area. As a verb, to draw the } \\
\text { audience's attention away from another actor onstage" (Gardner and } \\
\text { Diaz 208). }\end{array}$ \\
\hline 17 & anthropo-morphism & $\begin{array}{l}\text { "The attribution of human motivation, characteristics, or behavior to } \\
\text { nonhuman organisms or inanimate objects" ("anthropomorphism") }\end{array}$ \\
\hline 18 & set & $\begin{array}{l}\text { "The stage dressing for a play, consisting of backdrops, furniture and } \\
\text { similar large items" (Gardner and Diaz 204). }\end{array}$ \\
\hline 19 & naturalistic acting & $\begin{array}{l}\text { "A style of writing or acting meant to mimic closely the patterns of } \\
\text { ordinary life" (Gardner and Diaz 198). }\end{array}$ \\
\hline 20 & act & $\begin{array}{l}\text { "One of the principal divisions of a full-length play" (Gardner and } \\
\text { Diaz 185). }\end{array}$ \\
\hline 21 & anagnorisis & $\begin{array}{l}\text { "A significant recognition or discovery by a character, usually the } \\
\text { protagonist, that moves the plot forward by changing the } \\
\text { circumstances of a play" (Gardner and Diaz 186). }\end{array}$ \\
\hline
\end{tabular}




\begin{tabular}{|c|c|c|}
\hline 22 & unities & $\begin{array}{l}\text { "The elements of a play that help an audience understand the play as } \\
\text { a unified whole. Aristotle commented on the unities of time (the } \\
\text { action of a play usually takes place within approximately one day) } \\
\text { and action (the play should have a single, principal plot line)" } \\
\text { (Gardner and Diaz 208). }\end{array}$ \\
\hline 23 & hamartia & $\begin{array}{l}\text { a flaw in the protagonist's character that allows us to sympathize with } \\
\text { her/him, making the character more human, e.g. hubris which means } \\
\text { to have excessive pride ("hamartia") }\end{array}$ \\
\hline 24 & catharsis & $\begin{array}{l}\text { "A purging of the emotions of pity and fear. Aristotle argued in } \\
\text { Poetics that catharsis is the natural, and beneficial, outcome of } \\
\text { viewing a tragedy" (Gardner and Diaz 188). }\end{array}$ \\
\hline 25 & aside & $\begin{array}{l}\text { "A brief bit of dialogue spoken by a character to the audience or to } \\
\text { him- or herself and assumed to be unheard by other characters } \\
\text { onstage" (Gardner and Diaz 187). }\end{array}$ \\
\hline 26 & black comedy & $\begin{array}{l}\text { "A type of comedy in which the traditional material of tragedy (that } \\
\text { is, suffering, or even death) is staged to provoke laughter (Gardner } \\
\text { and Diaz 187). }\end{array}$ \\
\hline 27 & catastrophe & $\begin{array}{l}\text { "The final event of a tragedy, which brings about the fall or death of } \\
\text { the protagonist. In plays other than classical tragedy, a denouement } \\
\text { takes the place of a catastrophe" (Gardner and Diaz 188). }\end{array}$ \\
\hline 28 & comedy & "a play intended to be funny" (Gardner and Diaz 189). \\
\hline 29 & comic relief & $\begin{array}{l}\text { "A funny scene or character appearing in an otherwise serious play, } \\
\text { intended to provide the audience with a momentary break from the } \\
\text { heavier themes of tragedy" (Gardner and Diaz 189). }\end{array}$ \\
\hline 30 & denouement & $\begin{array}{l}\text { "Literally, "unknotting." The end of a play or other literary work, in } \\
\text { which all elements of the plot are brought to their conclusion" } \\
\text { (Gardner and Diaz 191). }\end{array}$ \\
\hline 31 & downstage & $\begin{array}{l}\text { "The part of the stage closest to the audience" (Gardner and Diaz } \\
\text { 191). }\end{array}$ \\
\hline 32 & elements of drama & $\begin{array}{l}\text { Aristotle: "plot, characterization, theme, diction, melody, and } \\
\text { spectacle" (Gardner and Diaz 192). }\end{array}$ \\
\hline 33 & exposition & $\begin{array}{l}\text { "A means of filling in the audience on events that occurred off-stage } \\
\text { or before the play's beginning" (Gardner and Diaz 193). }\end{array}$ \\
\hline 34 & falling action & $\begin{array}{l}\text { "The action after the climax in a traditionally structured play } \\
\text { whereby the tension lessens and the play moves toward the } \\
\text { catastrophe or denouement" (Gardner and Diaz 193). }\end{array}$ \\
\hline 35 & fourth wall & $\begin{array}{l}\text { "The theatrical convention, dating back from the nineteenth century, } \\
\text { whereby an audience seems to be looking and listening through an } \\
\text { invisible fourth wall, usually into a room in a private residence." } \\
\text { (Gardner and Diaz 195). }\end{array}$ \\
\hline 36 & proscenium arch & $\begin{array}{l}\text { "An arch across the front of a stage, sometimes with a curtain" } \\
\text { (Gardner and Diaz 202). }\end{array}$ \\
\hline 37 & rising action & $\begin{array}{l}\text { "The increasingly tense and complicated action leading up to the } \\
\text { climax in a traditionally structured play" (Gardner and Diaz 203). }\end{array}$ \\
\hline 38 & soliloquy & $\begin{array}{l}\text { "A speech delivered by a character who is alone onstage or otherwise } \\
\text { out of hearing of the other characters. . . a window into the } \\
\text { character's mind and heart" (Gardner and Diaz 204). }\end{array}$ \\
\hline 39 & subtext & $\begin{array}{l}\text { "The unspoken meaning, sense, or motivation of a scene or } \\
\text { character" (Gardner and Diaz 206). }\end{array}$ \\
\hline
\end{tabular}




\section{Works cited}

"anthropomorphism" Dictionary. http://www.dictionary.com/browse/anthropomorphism?s=t. Accessed 11 Oct. 2017.

Gardner, Janet E. and Joanne Diaz. Reading and Writing about Literature: A Portable Guide. 4th ed. Bedford/St. Martin's, 2017.

"hamartia" Literary Devices: Definition and Examples of Literary Terms. https://literarydevices.net/hamartia/. Accessed 10 Oct. 2017.

Jacobus, Lee A. The Bedford Introduction to Drama, 6th ed., Bedford/St. Martin's, 2009. 


\section{Bilaga 3: Written assignment: An Inspector Calls (1945) by J.B. Priestley}

\section{Instruction}

Write a literary essay of max one page (1.5 spacing) answering one of the questions below:

a) What methods does Priestley use in An Inspector Calls to highlight the theme of selfishness for the audience?

b) How does Priestley present Sheila in An Inspector Calls? (questions taken from Oxford Literary Companions, 2013, by Sue Fielder)

c) In what ways could this play be read as criticism of the hierarchal class structure in British society?

d) Choose a literary theory and analyze An Inspector Calls from that perspective.

Remember to support your argument with evidence from the text and use literary terms. Use at least one secondary source. Structure your essay in the following way: an introduction that ends with a thesis statement, a body paragraph with point, example, and explanation, and finally a conclusion. You also need to have a works cited list in accordance with the MLA referencing system (8th ed.).

NB! If you use ideas you have found on the Internet or elsewhere without citing the source that will be considered plagiarism. All cases of plagiarism will be reported to the Disciplinary Committee.

\section{Requirements}

- Formal writing and academic tone

- A persuasive text: State a thesis and then argue for it

- Support your argument with evidence from the play-text and the secondary source

- Use literary terms

- Structure your essay in the following way:

Follow the MLA style for documents = your full name in the left hand corner, my name, the course code, and the date (see Gardner and Diaz 165)

an introduction that ends with a thesis statement

body paragraphs (point, example, and explanation)

a conclusion

a works cited list

\section{Grading criteria}

For the grade Pass

1) Use evidence from the primary source to support your claims

2) Adhere to the conventions of formal writing 
3) Show adequate language skills

4) Apply basic literary terminology

For the grade Pass with Distinction in addition to the criteria for Pass you should also

1) Use an academic tone consistently

2) Show independent reasoning when analyzing the course material

3) Use the MLA reference style correctly 


\section{Bilaga 4: Instruktion för muntlig tentamen på litteraturvetenskaplig terminologi}

The module finishes with an oral exam in week 50. In the exam, you will need to be able to demonstrate your knowledge of the literary terminology covered during the module.

You will first be given a question about a literary term* (in writing). You will then have 5 minutes to prepare an answer to the question and to think of an illustrative example from the texts studied during the module. After this you will be asked follow-up questions (orally) that require additional analysis and evaluation of the course material.

You will be assessed against the grading criteria that apply in all of the literature modules. Below we've given you some examples of what kinds of things we'll be listening for when assessing your contribution.

*) Please note that the question may be about any of the terms covered during the module - it may deal with narrative or drama and may be drawn from Gardner and Diaz, any of the other secondary sources or the lectures. 


\section{Bilaga 5: Questionnaire on Literary Terminology (Term 1)}

1. What is your opinion of literary terminology?
a) It is a useful tool for analysis
b) It may be useful, but only for those who are interested in literature
c) It is just a lot of fancy words
d) None of the above? Please write your own comment below.

2. Which would you prefer that the teacher does in order to help you learn literary terms?
a) Go through them in class
b) Organize group activities that force students to explain and revise them together
c) It does not matter since I prefer to learn them on my own
d) None of the above? Please write your own comment below, thank you.

3. If you can remember, please list some of the literary terms that you learned in the courses in literature.

4. Could you please describe what you think is the effect on the reader of one of those literary terms?
a) Chosen literary term:
b) Effect on the reader:

5. Do you think that you will use literary terms in the future?
a) Yes
b) Perhaps
c) $\mathrm{No}$
d) Any further comments? Please write those below. Thank you.

6. Have you encountered any of the literary terms in your private life, outside of class?
a) Yes
b) I don't know
c) $\mathrm{No}$
d) Any further comments? Please write those below. Thank you.

7. Do you think that using literary terms is necessary when writing an essay on literature?
a) Yes
b) I don't know
c) $\mathrm{No}$
d) Any further comments? Please write those below, thank you. 
8. When did you learn how to analyze literature?
a) In secondary school
b) In upper secondary school
c) On the G1 level
d) None of the above? Please write your own comment below.

9. Was writing in English about literature different from other types of academic writing that you have done?
a) Yes, very different
b) Only slightly different
c) No, it was the same
d) Any further comments? Please write those below, thank you.

10. What was the most difficult when writing the assignments this term?
a) The structure (what to include and where)
b) The reference system
c) The framing of the argument (how to write about the topic)
d) None of the above? Please write your own comment below.

11. What kinds of comments are helpful for you as feedback?
a) Praise
b) Criticism
c) Questions
d) None of the above? Please write your own comment below. 


\section{Bilaga 6: Questionnaire on Literary Terminology (Term 3/5)}

1. What is your opinion of literary terminology?
a) It is a useful tool for analysis
b) It may be useful, but only for those who are interested in literature
c) It is just a lot of fancy words
d) None of the above? Please write your own comment below.

2. What would you prefer that the teacher does to help you learn literary terms?
a) Go through them in class
b) Organize group activities that force students to explain and revise them together
c) It does not matter since I prefer to learn them on my own
d) None of the above? Please write your own comment below, thank you.

3. If you can remember, please list some of the terms that you learned in the courses in literature.

4. Could you please describe what you think is the effect on the reader of one of those literary terms?
a) Chosen literary term:
b) Effect on the reader:

5. Do you think that you will use literary terms in the future?
a) Yes
b) Perhaps
c) $\mathrm{No}$
d) Any further comments? Please write those below. Thank you.

6. Have you encountered any of the literary terms in your private life, outside of class?
a) Yes
b) I don't know
c) $\mathrm{No}$
d) Any further comments? Please write those below. Thank you.

7. Do you think that using literary terms is necessary when writing an essay on literature?
a) Yes
b) I don't know
c) $\mathrm{No}$
d) Any further comments? Please write those below, thank you. 
8. When did you learn how to analyze literature?
a) In upper secondary school
b) On the G1 level
c) On the G2 level
d) None of the above? Please write your own comment below.

9. How did you decide what to write about in the literary work that you chose for the G2 essay
a) I chose aspects that I was interested in
b) I was inspired by the secondary sources
c) I just picked something at random
d) None of the above? Please write your own comment below.

10. Was writing in English about literature different from other types of academic writing that you have done?
a) Yes, very different
b) Only slightly different
c) No, it was the same
d) Any further comments? Please write those below, thank you.

11. What was the most difficult to learn when writing the G2 essay?
a) The structure of the essay (what to include and where)
b) The reference system
c) The framing of the argument (how to write about the topic)
d) None of the above? Please write your own comment below.

12. What kinds of comments are helpful for you when working on the essay?
a) Praise
b) Criticism
c) Questions
d) None of the above? Please write your own comment below. 